received from the Geological Survey of the Gold Cosst Colony, and Prof. Takeo Watanabé has presented a specimen of the new mineral kotoite- $-a$ magnesium borate occurring as a rock-forming mineral in limestone in Korea. A magnificent group of yellow and green zoned crystals of fluor from a mine in Weardale has been purchased and the opportunity has been taken to re-arrange the exhibit of fluor in the pavilion of the Mineral Gallery. Mr. P. M. Game, a member of the staff of the Department of Minerals, who recently returned from an expedition to West Greenland under the leadership of Dr. H. I. Drever, has brought back a collection of about three hundred specimens of rocks and minerals from Ubekendt Island, Umanak Fjord, a region in which no previous geological work had been done.

THE Department of Botany has received two collections of plants from expeditions made by students of Imperial College. The first is from Jan Mayen, and contains 427 numbers mostly collected by Mr. R. S. Russell. The collection is a very valuable one as each number usually contains ample material. The Department now has practically a complete representation of the species recorded from the island, which is of special interest in view of its position in mid-ocean between the Old and the New Worlds. The second is from Finmark, and consists of 350 numbers of dried plants and some fungi in spirit, collected for the most part by Mr. H. D. Jordan. The specimens are mainly from the base camp area at the head of Lakse Fjord and in the still incompletely mapped hinterland, which was crossed up to a little beyond River Tana. The Oxford University Expedition to the Cayman Islands obtained 678 numbers of flowering plants and 614 numbers of cryptogams for the Department, collected by Mr. W. Kings. The specimens are well preserved, and, as the islands are little known botanically, the collection should prove an interesting one. Mr. C. A. Lister accompanied the Public Schools Exploring Society's Expedition to Newfoundland and collected 173 phanerogams and 34 cryptogams. These have been presented to the Department and supplement the previous collections made in these expeditions. The specimens are very well preserved. The British herbarium of the late Mr. F. J. Hanbury, which was bequeathed to the Museum, contains more than 20,000 sheets. As Mr. Hanbury always aimed at a large series of specimens and as he was responsible for a considerable number of records to the "Supplements to Topographical Botany", the material is especially useful. The chief value of the herbarium is probably in the fine collection of Hieracium, for Mr. Hanbury began the publication of a monograph of the genus and compiled the account in the ninth edition of Babington's "Manual" ; it contains the Hieracia of James Backhouse, the first monographer of the genus in Britain. The Department has also acquired Lieut.-Colonel A. H. Wolly-Dod's collections of Rosa. Colonel Wolly-Dod is the recognized British authority on the genus, and many of the specimens have been examined by other specialists.

\section{Philosophy and History}

IN the annual philosophical lecture on "Some Problems of the Philosophy of History" delivered under the Henriette Hertz Trust before the British Academy on March 16 (London : Oxford University Press, 1s. 6d. net), Prof. G. C. Field urged that all serious philosophical thinking must be based on an examination of the assumptions actually made in the other established forms of thinking. If the philosopher wishes to proceed eventually to a general theory of knowledge or reality, he must take this as his founda. tion and evidence. Prof. Field suggested that among the established forms of thinking, history holds an important place and deserves serious consideration in view of the tendency to suggest that the assumptions of physical science must be the assumptions of all valid thinking. History forms a coherent body of thought in which mutual understanding and cooperation between large numbers of people are possible, and has independent claims to consideration as an essential part of the evidence on which our final theories must be based. Prof. Field distinguishes three main elements in the general structure of historical thinking: imaginative reconstruction of past events or situations; the belief that this imaginative reconstruction is correct, corresponding to, or being like in some degree, what really happened; and the evidence on which our conclusions are based. Discussing the dependence of our historical beliefs on narrative, he referred to the question of selection in imaginative reconstruction and its bearing on the understanding rather than the mere recording of what happened.

\section{University of Manchester and its Alumni}

THE second number of the Journal which the University of Manchester has established as a means of keeping its members in touch with its activities and plans maintains the high standard of its predecessor. A message and appeal to its graduates by the Vice-Chancellor is followed by a number of articles of more than local or passing interest. The School of History, the Physics Department, the University Settlement and Halls of Residence are discussed by Profs. E. F. Jacob and W. L. Bragg, Mr. Pilkington Turner and the wardens of two of the Halls. Mr. John Coatman, North Regional director of the B.B.C., writing on "The Significance of a Lancashire University in the Community", argues ingeniously that the circumstances of to-day call for a vision of international economic and political relations as clear and fruitful as that which gave Lancashire its greatness a century ago, and that, to meet this need, its universities, the county's "great intellectual power-houses", should devote themselves increasingly to the "philosophical study of the principles of human association, examination of the economic and political forces at work inside and between nations, and clear-sighted, intelligible analysis of the forces which mould public opinion, determine national policies, and thus in the end control international relations". Furthermore, he urges that in the systems of education which come within their influence they should give an increasing 